\title{
Chance in the Hebrew Bible: Views in Job and Genesis 1
}

\author{
Ellen van Wolde
}

\begin{abstract}
There are a variety of views on 'chance' to be found in the Hebrew Bible, or Old Testament. In this chapter we will discuss the Book of Job and the opening chapter in the Book of Genesis, i.e. Genesis 1, both as narratives and as poetic texts and explore the philosophical and theological consequences for a better understanding of the concept of chance. In the prologue of the Book of Job, chance is referred to as the result of a wager between God and the satan, who is described as one of the sons of God. In the dialogue between Job and his friends, bad luck is viewed as a consequence of bad behaviour while good luck is the result of good behaviour. In this sense, chance clearly functions within a moral framework of retribution. At the end of the Book of Job, in God's speech out of the whirlwind, chance is linked to a multifocal view of the universe and understood in terms of position, perspective, and scale. Also the opening chapter of the Book of Genesis offers a non-deterministic view on chance. Chance is not the exception in a causal or necessary chain of events, but it stands out in a framework of non-linear thinking in which totality and instantaneity alternate. With regard to both biblical texts, God's speech in the Book of Job and Genesis 1, chance can be conceived as a disqualifier of this chain of events, and even as an ultimate denial of the existence of necessity.
\end{abstract}

\section{The Prologue of the Book of Job: Chance as a Wager}

Job's life is going well, very well indeed. Job is rich, wealthier than anyone in the East. He has a large herd of cattle, a huge number of employees, and a very large household. Above all, he has the family that every rich man desired at that time, namely seven sons and three daughters. Who could wish for more? Because of these blessings, or maybe by choice, Job lives his life as righteously as he can,

E. van Wolde $(\square)$

Faculty of Philosophy, Theology and Religious Studies, Radboud University, Nijmegen,

The Netherlands

e-mail: e.vanwolde@ftr.ru.nl

(C) The Author(s) 2016

K. Landsman and E. van Wolde (eds.), The Challenge of Chance,

The Frontiers Collection, DOI 10.1007/978-3-319-26300-7_7 
treating others as he would wish to be treated. Because he is an honest, upright, and god-fearing man, people respect him. Suddenly, seemingly by chance, bad luck strikes. One day as his sons and daughters socialise with their friends, a terrible storm arose and lifted the roof off smashing it back down onto the group. They are all killed in an instant - no one survives. The servants have to break this dreadful news to their master. Then, barely has one disaster struck when another employee rushes in from the fields to tell Job that cattle-thieves have stolen all his livestock: thousands of oxen, she-asses, sheep, goats and camels are gone. Within the wink of an eye this god-fearing man who had everything has lost everything.

This story of devastating misfortune is told in the book of $\mathrm{Job},{ }^{1}$ one of the books in the Hebrew Bible. ${ }^{2}$ Surprisingly, chapters 1 and 2 already offer an explanation why this happened. It seems that Job's misfortune, or the shift from fortune to misfortune, was the consequence of a deal made in heaven. Through the description of a meeting by the divine council we find out what lay behind Job's misfortune from heaven's perspective. In this meeting, Yahweh ${ }^{3}$ opens the discussion by asking a fellow divine being, ${ }^{4}$ one of the sons of God called the satan, ${ }^{5}$ the

\footnotetext{
${ }^{1}$ Most scholars today would date the composition of the Book of Job to some point between the seventh and fourth centuries BCE. There are a number of indications in the book that it was not written all at one time, but went through a phases of composition. In the most recent monography on Job (Seow 2013, pp. 40-44), the Book of Job is dated to the late sixth to mid-fifth century BCE. Seow's arguments are based on literary parallels to Deutero-Isaiah and Zechariah 3, as well as to the historical reference to the Chaldeans in Job 1:17.

${ }^{2}$ Some of the most comprehensive and recent monographs on the book of Job are: Habel (1985); Clines (1989-2009); Newsom (2003); Seow (2013).

${ }^{3}$ The notion of 'God' or 'deity' is expressed in Biblical Hebrew by the word 'elōhîm, a plural noun of the singular form 'el or 'eloah, 'God', and this plural noun is commonly used with a singular verb form. The personal name of the God of Israel is $y h w h$, Yahweh. In the Hebrew Bible sometimes reference is made to the God of Israel by its common name 'elōhim, other times by the personal name $y h w h$. In the Book of Job both terms are used to designate the deity (see, e.g., here in Job 1:6: "the sons of 'elōhim presented themselves before $y h w h$ "; or Job 1:21 where Job says: " $y h w h$ has given, $y h w h$ has taken away"; see also Job 2:10, in which Job says to his wife: "Should we accept good from the hands of the deity (ha-'elōhim), should we not accept evil?"). Throughout this chapter I will refer to 'elōhim or $y h w h$ by the term 'God', with the exception of literally quoted verses.

4'Sons of God' or 'divine beings' (in Hebrew benê-'elōhîm or benê-'elîm) figure in several passages in the Hebrew Bible and designate the divine beings that live in heaven and are seen as closely related to Yahweh or to Elyon, 'God, the most high'. The notion of a 'divine council' denotes a formal gathering of these 'sons of God' and this council is viewed as the godly government, which most likely resembled the earthly royal court. The earthly and heavenly councils formally operated in two ways: the first way would be an advisory board for the king/deity regarding matters of state or government; the second way was as a formal judicial court. For extensive discussion, see White (2014). Reference to these divine beings and/or a divine council is made in the Hebrew Bible in: Gen. 1:26; 3:22; 11:7; Exod 15:11; Deut 4:19; 17:3; 32:8; 33:2-3; Judg. 5:20; 1 Kg 22:19-23; Isa 6; 14:13; Jer 8:2; 23:18.22a; Am 8:14; Sach 3; 14:5; Pss $25: 14 ; 29: 1-2 ; 49: 20 ; 58: 1-2 ; 73: 15 ; 82 ; 89: 6-9 ; 96: 4-5 ; 97: 7-9 ; 148: 2-3 ;$ Job $1-2 ; 15: 8 ; 38: 7$; Dan 7:9-14; Neh 9:6; 1 Chron 16:25 (book order follows the Hebrew canon).

${ }^{5}$ 'The satan' is the translation of ha-satan (in Hebrew this is the nominalised form of the participle of the verb satan 'accuse', preceded by the definite article $h a$-) and the definite article indicates that
} 
following question. "Have you noticed my servant Job? There is no one like him on earth, a blameless and upright man who fears God and shuns evil!" The satan replies, "Is it 'for naught' (Hebrew chinām) that Job has put his faith in you? You have protected him, all his life." In this sense, the satan argues that the principle of retribution, ${ }^{6}$ or 'tit for tat', drives human behaviour, including Job's model behaviour. In other words, the satan claims that Job puts his faith in God only because God protects him and to make sure things go well for him. God takes the opposite position. Simply put, God assumes that Job is pious at the same time as being rich, whereas the satan claims that Job is pious because he is rich and wants to stay rich. Challenged by the satan, God places his bets on Job. It is an important question for God: do people fear God unconditionally or do they put their faith in him in order to ensure they stay well off? ${ }^{7}$ God cannot test everyone so he puts Job, the epitome of a pious man, to the test. The aim is to answer the following questions: is people's loyalty to God pure, that is to say not driven by self-interest? Are disasters the consequence of bad behaviour or caused by a lack of trust in God? Do human beings who live a good life deserve happiness? Did Job deserve happiness? Is there any rationality behind the alternation of fortune and misfortune on earth? To demonstrate the significance of these questions, the narrator sets the exchange between God and the satan in heaven. Here the discussion between God and the satan can be more open and intense. However, only the readers know about the wager. The character Job knows nothing of this heavenly experiment.

The next scene is set on earth and shows how Job reacts when blow after blow strike. Although deeply miserable and unable to understand what is happening to him, he does not blame God. Instead he says: "Naked I came from my mother's womb, and naked I shall return. Yahweh has given and Yahweh has taken away; blessed be the name of Yahweh" (Job 1:21). The interesting point of this response is that Job does not consider misfortune as mere bad luck or as something inexplicable that happened by accident, but he attributes everything, either good or bad, to God. Job's position, therefore, is one of complete faith or trust.

But then, new disasters strike Job. This time his body is affected and his skin peels away until his body is raw. Eventually he ends up in a rubbish dump covered

\section{(Footnote 5 continued)}

'the satan' does not express a name, but refers to someone who performs the task of 'accusing'. Figuring in a judicial court, one might translate 'the satan' with 'the (public) prosecutor'. In the divine council operating as a judicial court (see note 4), the various divine beings each play their own role: the satan acts as the public prosecutor, while (the highest) God acts as the judge, and the malach (traditionally translated with 'angel') functions as the messenger who brings the divine judgements as messages to the human beings.

${ }^{6}$ The term retribution derives from the Latin retribuare, 'to pay, grant, repay'.

${ }^{7}$ The modern terminology 'to believe in God', 'to love God', or 'to have pure faith' does not adequately reflect the idea of 'to fear God'. In the Hebrew Bible, 'to fear God' includes notions like 'trust', 'respect', 'awe' and 'loyalty', which figure in a hierarchical framework of thinking. The adequate human expression of this fear is 'to serve God'. The question in Job's prologue is, therefore, do human beings fear God because they trust and respect God, or, in contrast, because they expect reward and try to avoid punishment? 
with loathsome ulcers from the soles of his feet to the crown of his head. He scratches himself with a pot shard but still he utters no reproach. Suddenly Job's wife turns up. Where did she come from? She was not mentioned before. ${ }^{8}$ The narrator told us about Job's sons and daughters but never mentioned a wife, and when he lost his offspring there was no reference to her either. In his deepest misery Job says that he is all alone in the world ("naked I came, naked I will go") without mention of a wife - apparently she does not count. Yet, now Mrs. Job enters the picture and challenges her husband: "Do you still keep your integrity? Say good-bye to God ('elohîm) and die" (Job 2:9). In a way, Job's wife draws the same conclusion that many secular readers would draw under similar circumstances. Embedded in her words are questions such as: "How can you keep on being loyal to God when all this misfortune befalls you? Why are you being targeted? You, my dear husband, do not deserve this. You live an upright life, I can testify to it." Job's wife is motivated by the principle of causality as the steering principle of faith: you place your trust in God since he is the one who made you, supports you, perhaps, even punishes you when you deserve it. There appears to be balance in this God-created universe. But disaster and misery prove that such a balance does not exist, so you might as well give up your loyalty to God. Modern secular people would add: it is not just the fact that this cosmic order does not exist, but the so-called originator and defender of this cosmic order does not exist either. This would be unthinkable in the context of ancient Near Eastern culture. Here in this text the phrase is: 'Say adieu to God'; the existence of God is not at issue. Nevertheless, this farewell to God is what Job's wife proposes and we, as modern readers, are likely to agree with her as we often understand misfortune in individual lives or in nature as evidence of the non-existence of God.

Yet, Job contests this view fiercely. He dismisses his wife's words as foolish: "Should we accept good from the hands of the deity, but should we not accept evil?" (Job 2:10). Still, her words have an effect. By confronting Job with his own death and pointing out to him the choice between blessing God or saying good-bye to God, she forces him to respond. The difference between the wording of Job's first reaction in Job 1:21 "'Yahweh has given and Yahweh has taken away; blessed be the name of Yahweh") and his response to his wife is striking. The first time Job speaks he refers to God by the name Yahweh. Thus Job acknowledges Yahweh as Lord. The second time, immediately following his wife's remarks, Job speaks about God as 'the deity', ha-'elohîm. Although Job still considers God as the agent or distributor of good and bad luck, this sounds more detached. In addition, whereas

\footnotetext{
${ }^{8}$ Her namelessness, her absence in chapter 1 , her short and unclearly presented speech in chapter 2, and her departure after the second chapter of the book of Job never to return in the rest of the book, have aroused interpreters' interest in Job's wife throughout history. From the Greek translation of the Hebrew Bible in the Septuagint (third century BCE) in which a section on her is added to the translation, through the interpretation history of the Bible, to contemporary novels and theatre plays, Mrs. Job has received much more attention than in the biblical book of Job. For a recent survey, see Gravett (2012, pp. 97-125). For a textual analysis of Job 1-2 and of the narrative function of Job's wife, see: van Wolde (1995, pp. 201-221).
} 
the first reaction was a statement, the second is formulated as a question. And Job who first choses to bless God (in Job 1:21) now stops blessing God. His wife introduces the notion of death and this instils doubt in Job. He is no longer sure of anything and begins to ask himself questions. He even starts to reason from a human point of view instead of automatically adopting the perspective of God. His wife's taunts trigger Job to change from an assured believer into someone who asks questions. The responses of an ardent believer would not have provided material for such a dramatic story. The book of Job is made human and lifelike through the doubt and spirit of a man who has to confront his trust in God in the light of the suffering, misery and undeserved and devastating bad luck that has befallen him.

Thus the opening chapters of the book of Job explore the theme of chance through narrative. What seems to be an inexplicable change of fortune on earth is described as the consequence of a wager in heaven. The bet turns out to be a kind of empirical research. God's hypothesis is that people serve him 'for naught'. His is a framework of non-causality. The counterhypothesis, formulated by the satan, is that people serve God in order to secure a better life for themselves. His framework is one of causality. The test is performed on God's model servant on earth, Job. The concept of chance thus figures in the domain of causality. By alternating between scenes on earth and scenes in heaven, the reader is able to view the topic from two perspectives through the characters in the two domains, i.e. God and the satan in heaven, and Job and his wife on earth. By positioning the four characters in a kind of matrix, the narrator reveals his preferences. The narrative strategy of Job 1-2 is to convince readers to share both God's and Job's point of view and agree with them that it is enough to accept that everything (good luck and bad luck) is given or taken away by God. God and Job conclude that the satan and women (not just Job's wife) hold a point of view is seductive but incorrect. However, by introducing these opposing characters, readers are challenged to consider questions such as: Are the concepts of causality and retribution helpful in understanding the incidence of fortune and misfortune in someone's life? Are patterns of regularity, logic and ethical balance sufficient to explain the unexpected disruptions in someone's life or not?

\section{Dialogue in the Book of Job: Chance as Proof of Moral Balance}

Job's friends know the answers to these questions. In endless discussions (Job chapters 4-37), usually called 'dialogues', Job and his friends defend the view of a moral balance in the world in various degrees. ${ }^{9}$

\footnotetext{
${ }^{9}$ For an extensive description of the dialogue sections, see: van Wolde (2003, pp. 42-106).
} 
Eliphaz is the first of Job's friends to speak and his speech is characterized by dignity, sobriety and reticence. The nub of what he wants to say is: "Is not your fear of God your confidence and the integrity of your life your hope?" (Job 4:6). Job can be reassured precisely because he believes in justice and knows that God guarantees that human beings will be recompensed in accordance with their behaviour, good or bad, says Eliphaz. He thus sketches a hopeful future for Job. The second friend, Bildad, is less optimistic. He calls God a just judge and in his view there is no doubt that God administers law in the right way. Bildad even goes as far as seeing God's justice illustrated by the fate of Job's sons: they partied too much and have sinned so they were punished. In actual fact, his argument is back to front: because Job's sons were punished, they must have sinned. The third friend, Zophar, even goes one step further. He identifies where Job went wrong and explicitly condemns the process that Job is going through, since he understands that Job risks throwing the whole of the traditional doctrine of retribution overboard. Zophar's reaction is caustic and what he says can be summarized as follows: "don't think that you can understand everything by your talk and chatter. It cannot be grasped at all, so submit to the traditional views and know that God's justice is a great mystery". Thus Zophar puts Job's behaviour to shame. In contrast to Eliphaz, who regarded Job as innocent, and Bildad, who regarded the sons as guilty, Zophar now accuses Job outright of sin and calls on him to repent.

Job's friends' views on misfortune and chance clearly function within the moral framework of retribution. David Clines, one of the most prominent Job scholars of our times, offers a fair reflection on their position:

Now it is very easy to mock the friends' concept of God as the executor of retribution, and to point to the myriad of examples we all know in which reward has been denied the godly and the wicked have escaped punishment. Yet the alternatives to this theology may be worse still: imagine a world in which there is simply no predictable correspondence between act and consequence. How will any parent inculcate right behavior in children, how will any state warn the criminally inclined, if there is no underlying principle of retribution? The attractiveness of the theology is that it is not purely experiential and anecdotal, an accumulation of instances, but a systematic, principled thinking through of the way the world ought to work, should be governed, must be conceived. It posits a fundamental justice at the heart of God's design for the universe. From this perspective, any number of examples, or apparent examples, where it fails to be implemented cannot subvert the principle, foralthough it is often stated as an account of what actually happens in the real world - it is not so much a description of reality as a blueprint for it. (Clines 2004, p. 42)

Job, as a man who fears God and shuns evil (Job 1:1), had long accepted the same theology. But since he has experienced a refutation of that theology at first hand, his whole view of God's justice is called into question. He draws the bitter conclusion that there is no retribution and that there is no justice. His personal tragedy has led to disillusionment with God and the whole of the moral universe. 


\section{God's Answer "Out of the Whirlwind"}

Surprisingly, in the book of Job, God's speech out of the whirlwind is presented in the form of an answer to Job: "Then, Yahweh replied to Job out of the whirlwind and said" (Job 38:1). God's answer, which stretches out over four chapters (Job 3841 ), is set in a poetic style, with short sentences, fixed rhythms, and multiple series of rhetorical questions, which very often open with the interrogatives 'who', 'when', 'where', 'what', or 'do you know'? Yet, a real answer to the earlier questions posed, it is not. It seems more of a monologue in which God does not really react to Job's questions and cry for justice. God's first words to Job are full of significance: "Who is this who darkens counsel, speaking without knowledge?" (Job 38:2). God reproves Job for setting his own agenda. In his quest for justice, Job obscures the fact that God does nothing to ensure that justice reigns in the world. God speaks about a completely different order, when he continues, "Where were you when I laid the earth's foundations? Speak if you have understanding." (Job $38: 4)$. God not only points out their varying levels of knowledge, but also Job's physical location. God refers to Job's position as well as his implied spatial limits and, accordingly, limited perspective (Joode 2015, pp. 198-199). In fact, God's spatial scale is of a different order. Not only does he know everything about the created universe, he is its architect. "Do you know who fixed its dimensions? Or who measured it with a line? Onto what were the earth's bases sunk? Who set its corner stone? When the morning stars sang together and all the divine beings ${ }^{10}$ shouted for joy?" (Job 38:4-7) ${ }^{11}$ And God continues: "Have you penetrated to the sources of the sea? Or walked in the recesses of the deep? ${ }^{12}$ Have the gates of death been disclosed to you? Have you seen the gates of deep darkness? Have you surveyed the expanses of the earth? If you know of these, tell me" (Job 38:16-18). Again and again, Job is forced to acknowledge his limited position, limited perspective, and, therefore, his limited knowledge.

Later, God carries on asking about all kinds of animals ${ }^{13}$ implying that in their own way they have all the freedom to reproduce and treat their young as they see

\footnotetext{
${ }^{10}$ For divine beings, see footnote 4 . In Mesopotamia the stars are conceived as the heavenly manifestations of deities, and hence as divine beings. The same divine beings are at the same time physically present on earth, e.g. in statues (inaugurated after mouth-washing rituals) or in temples. This fluidity of the divine selfhood in Mesopotamia, Canaan and possibly also in the Hebrew Bible is discussed in Sommer (2009).

${ }^{11}$ The translation of the verses in Job 38-39 is the Jewish Publication Society's-translation.

${ }^{12}$ For the tripartite worldview behind these questions (heaven, earth, and tehom or 'the deep'), see below the first paragraph in the section on Genesis 1 .

${ }^{13}$ E.g. Job 38:39 and 39:1-4: "Can you hunt prey for the lion? And satisfy the appetite of the king of beasts? They crouch in their dens, lie in ambush in their lairs. Do you know the season when the mountain goats give birth? Can you mark the time when the hinds calve? Can you count the months they must complete? Do you know the season they give birth? When they couch to bring forth their offspring, to deliver their young? Their young are healthy; they grow up in the open. They leave and return no more."
} 
fit. In a long series of rhetorical questions, God reflects on the universe and its inhabitants, showing that he infused all entities and creatures with wisdom so that they would be capable of acting on the own accord. Creatures reproduce, nurture and sustain themselves and their offspring in their own ways and God does not need to know everything they do. He does not watch over the mother ostrich when she decides to hide her eggs, forgetting that other animals could tread on them. ${ }^{14} \mathrm{He}$ does not get involved in the moral convictions of human beings who want him to share their ideas of justice. There is a universal order, which God upholds, but its principles are not balance and equity, or retribution and equivalence, as Job and his friends seem to think. God's principles are more strategic and focus on intimate knowledge, sustenance and variety (Clines 2004, p. 48). In his discourse, God knows his universe intimately, but he does not tell the stars or the earth's inhabitants what to do and how to behave. The purposes of the universe are infinitely multiple, each of its elements has its own perspective and rules. As for humans, they are merely one part. The world has not been designed just for them. If they want to up hold justice they must to do it themselves, according to their own rules.

Finally, the theology of the divine speech contains an implicit answer to the satan's question: Does Job serve God chinām? The satan had suggested that Job was pious because he found it benefitted him to be pious. Job's behaviour in the opening chapters proves he is pious 'without cause' but now, in the divine speech, this question is raised again in a different sense. Since the divine speech denies that there is a causal relationship between deed and consequence, it follows that every deed is done for free, without a reason and without reward (Clines 2004, p. 49). There is no principle of retribution at work in the universe. Any system of moral causation, of moral order, will not be from the universe or God, but will be made and maintained by human beings.

\section{Chance in the Book of Job}

At the start of the Book of Job, readers are confronted with Job's fate and we cannot but feel compassion for him. Yet, as readers we know that what appears to be bad luck for Job on earth is actually a consequence of the wager in heaven between God and the satan. It is this dynamic interaction between the heavenly wager and its impact on earth that makes the risk of good or bad luck acceptable to readers of the Bible. This bi-focal perspective disappears in the dialogues between Job and his friends, since here the friends present their respective mono-focal views, in which chance clearly functions within a moral framework of retribution and is reduced again to a simple balance. However, by the end of the Book of Job when we read about God's speech out of the whirlwind, these simplistic views are replaced by a multifocal view of the universe in which chance is understood in terms of

\footnotetext{
${ }^{14}$ See Job 39:13-16.
} 
perspective, place and scale. In a long series of rhetorical questions God reflects on the universe and its inhabitants, showing every phenomenon's spatial limitedness, bound to each limited perspective. What is considered unacceptable or unjust on one scale may be explicable on another scale, and vice versa. Thus the Book of Job advocates a perspectival and scale dependent view on causal chains and events that cannot be reduced to human explanations and simple schemes of retribution.

This non-deterministic framework we see in the Book of Job has not played a major role in Jewish and Christian theologies. Like the satan, Job's wife and Job's friends, people continue to ground their faith in God on causality and explain life in a deterministic framework. That is to say, people develop causal explanations for the sometimes inexplicable alternation of events, with their brains and rationality, and then they make God responsible for what they consider to be a 'reasonable' or 'necessary' chain of events. They blame God for bad luck, injustice, natural disasters, and in this find a reason to conclude that God does not exist. God's speech in the Book of Job invites its readers to examine their views on the topic of chance as this exposes the human quest for causal explanations as a result of a human need for moral order, logical structure, and a system they can understand. The text teaches us to consider chance as the residue of our quest for necessity, for moral and logical patterns and our desire to call patterns God's design. The Book of Job does not present its teachings through an abstract discourse, a learned essay, or a treatise with generalizations. It offers narrative and poetic material ${ }^{15}$ that reflects ambiguity, and uses a matrix of characters' perspectives to challenge us to make up our own minds on the topic of justice, moral and logical order, and chance.

\section{From Narrative to Philosophy}

If we turn from the literary aspects of the Book of Job with its discussions on the moral balance in the world to the deterministic views on chance that have dominated Orthodox Judaism and Orthodox Christianity, we discover elements that still influence present discussions on rationality and faith. Orthodox Jewish tradition has adhered to a theology that celebrates Yahweh, the God of salvation, who elected his people Israel out of the nations, acted mightily for Israel at the exodus and at the conquest of the land, and gracefully in its offer of a covenant and of the Torah. In return, his people must acknowledge him as the one and only God, serve him and respect him, and live following his laws of covenant. Yahweh then will act as the executor of a system of retributive justice.

Orthodox Christian theology has followed Jewish tradition in this theology of retribution and has at the same time been influenced by Aristotelean ideas of

\footnotetext{
${ }^{15}$ The narrative style of chapters 1 and 2 in the Book of Job, characterized by sequential verbal forms, long sentences, embedded speeches of distinct characters, and an observable narrator's voice, differs greatly from the poetic style of God's speech in chapters 38-41, in which these characteristics are absent.
} 
regularity, causality, and coherence, in which God is the initiator of all changes in events. These religious deterministic worldviews are based on the convictions of a divine cosmic order as well as a divine moral order: God is the initiator and dominant agent behind all entities and the causal chains of events, and God upholds the moral order according to the principle of retribution. According to this retributionary view of God, those who act properly are rewarded with blessings, while wrongdoers are punished.

Today, most people in Western Europe no longer uphold these orthodox traditions. Nevertheless, in modern notions of chance, ideas of regularity and causality, which have their roots in ancient Christian adaptations of the Aristotelean conception of causality (cf. Hulswit 2002), often resurface. Aristotle, in particular, defined an 'efficient cause' as the primary source of change that is brought about for the sake of an end. As part of the Newtonian revolution in science during the seventeenth century, this concept of causality underwent a radical change, in that goals or ends were replaced by initial conditions, and causal relations became instances of deterministic laws. What remains unchanged, however, is the view that causal relationships were conceived as if they are ontologically there.

From Hume and Kant onwards, this view also started to be questioned. There was an awareness that causality presupposes selection or a predisposition that is created from the perspective of the rule or scientific law that the human mind accepts as such, but which may not be ontological. This development from ontology to epistemology in modern science and philosophy obviously has consequences for in understanding the notion of chance. See, for example, the position taken by Hume described in the first chapter of the present book The Challenge of Chance: "The chance or indifference lies only in our judgment on account of our imperfect knowledge, not in the things themselves, which are in every case equally necessary, though to appearance not equally constant or certain" (Hume, Treatise part 3, Sect. 1). Notice also Hume's conclusion that, "one should not suppose that the attributes of God have any analogy or likeness to the perfections of a human creature. (...) We ascribe to God Wisdom, Thought, Design, Knowledge (...) because these words are honourable among men, forgetting that $\mathrm{He}$ is infinitely superior to our limited view and comprehension" (Hume 1779, 46).

Surprisingly, this view expressed by Hume, and similarly by Kant, is not so very different from the position ascribed to God in the Book of Job. As shown above, God in his speech presented in Job 38-41 advocates a perspective and scale dependent view on causal chains and events that cannot be reduced to human explanations and simple schemes of retribution. God's position is non-deterministic and embedded in a framework where every living creature is responsible for his, her, or its own decisions that are necessarily limited in scale, time, place and position. The Book of Job does, therefore, not make God responsible for the chain of events. Even Leibniz, Clarke, or Hume would not dare to speak of God's decisions in terms of a betting game. Yet, the openings chapters of the Book of Job do talk about God's actions in this way. So Einstein's words that "God does not 
play dice" is in a way countered by Job. We could even conclude that the European philosophical tradition does not consist of "a series of footnotes to Plato" (as A.N. Whitehead famously held), but to footnotes to Job as well.

\section{From Philosophy Back to Narrative: Genesis 1}

Does everything that exists, have a beginning? Does everything that begins to exist have a cause? For aeons Christian theology offered an answer to these two questions by means of a notion commonly known as creatio ex nihilo: God 'created out of nothing', which contrasts with creatio ex materia 'creation out of some pre-existent, eternal matter'. Christian theology posited that all things, which have a beginning, must also have a source or cause, and that, because the universe has an apparent beginning, it must also have a transcendent cause. The idea of a beginning demands a creator who existed without a beginning and prior to and outside the universe. Currently, the general public (as can be seen on many websites) link the common phrase creatio ex nihilo to Genesis $1: 1$. This verse is considered to be a description of the first act by God through which everything came into being. The implication is that before this instant of creative action there was nothing: God did not make the universe from pre-existing material, but he started from scratch.

In the twentieth century, it became accepted in biblical scholarship that this idea of 'creation out of nothing' was not based on texts from the Hebrew Bible but on Greek texts (especially on 2 Maccabees 7 in the Septuagint) and on later interpretations influenced by Hellenistic philosophy. Over the last years, more nuanced studies have been written on 2 Maccabees 7, the Septuagint, and Hellenistic Jewish and Christian texts, showing that the idea of 'creation out of nothing' was not present in 2 Maccabees 7 and not elsewhere in the Septuagint, but was developed in the second century CE. ${ }^{16}$ In addition, new studies on creation texts in the Hebrew Bible have been published that demonstrate how these texts were conceived in a completely different intellectual framework than the later Jewish and Christian traditions. ${ }^{17}$ Yet, it is not the original ancient texts that influence the notion of 'creation out of nothing' in our times (the 21th century CE), but the reception and transformation of these texts by Christian traditions from the Early Middle Ages up to today. It turns out that texts in the Hebrew Bible never presupposed the concepts that lie at the heart of the creatio ex nihilo-theory, namely the concepts of nothingness and of material origins.

I will now focus on Genesis 1 to explain the cognitive framework of the ancient Near East in which Genesis 1 originated, a framework that differs from the Greek and Hellenistic framework and from medieval Jewish and Christian traditions.

\footnotetext{
${ }^{16}$ See Schmuttermayr (1973), O'Neill (2002), Niehoff (2013).

${ }^{17}$ See three of the most recent comprehensive studies of Genesis 1: Smith (2010); Walton (2011); Batto (2013).
} 
Subsequently, I show how this framework is different from the common understanding of Genesis 1 in modern non-academic and ecclesiastical circles that have been greatly influenced by these later Jewish and Christian traditions. Upon a sketch of the worldview this text presupposes, a short textual analysis of Genesis 1:1-3 will follow in order to elucidate the view this text offers of the beginnings of the universe. Finally, some of its consequences for our understanding of the notion of 'chance' will be drawn.

\section{Worldview in the Hebrew Bible}

"There is more between heaven and earth", in this and other everyday conversations it seems natural to make a distinction between heaven and earth. However, this is not as self-evident as it appears. The endless universe is, in fact, continuous and not split up into a heaven and an earth. Although the word string "heaven and earth" is used in the Hebrew Bible as a merism to express the totality of all and everything, biblical texts share the ancient Near Eastern view that the cosmos consists of at least three layers: heaven, earth and the netherworld. ${ }^{18}$ This tripartite cosmic view serves as a backdrop for all the texts in the Hebrew Bible.

The tripartite cosmic view is immediately apparent in the three opening verses of Genesis 1. God performs an action with respect to two direct objects, 'heaven' and 'earth'. The two nouns hāšàmayim, heaven(s), and hà'äres, earth, reflect the worldview that the universe consists of at least two components or levels. The following two verses presuppose another level in the universe below the earth, namely tĕhōm: the netherworld or abyss that is filled with water. What did the ancient Israelites think of when they spoke of těhōm? The Biblical material allows us to construe an inventory of the possible concepts underlying těhōm: it is conceived as (1) a spatial realm under the earth, (2) a vertical depth, (3) a large expanse of water expanded vertically and horizontally, (4) a container of water that is the source of springs, wells, fountains, and rivers on earth, and (5) a layer on which the earth rests. Based on the first two concepts, the semantic content of těhomm is considered in terms of depth and translated into English as 'the deep' or 'the abyss'. Based on concepts 3 and 4, the semantic content of těhom is considered in terms of huge volumes of water and translated into English as 'waters' or '(primeval) ocean'. In short, in the Hebrew Bible, the těhōm is clearly conceived as the lowest tier in the tripartite cosmos - a deep container filled with water.

Heaven is the highest tier, and biblical texts including Genesis (1:6-8) present the idea that heaven is made of solid vertically arranged material that holds volumes

\footnotetext{
${ }^{18}$ Cf. Cornelius (1994); Horowitz (1998); Pongratz-Leisten (2001); Keel and Schroer (2002); Walton (2011).
} 
of water in place. ${ }^{19}$ The function of this heavenly vault is to prevent the waters above the vault from falling down on the earth. The těhom or the spatial realm beneath the earth is also filled with water. Earth occupies a central position in the tripartite view of the cosmos sandwiched between heaven above and těhom below. Ancient maps, such as the Babylonian map in the British Museum and Greek maps drawn by Anaximander and Herodotus, share the belief that the inhabited world was a disk of earth surrounded by water. Biblical texts also conceive the earth as a single, disk-shaped continent surrounded by an ocean of water. The Hebrew word tebel refers specifically to this 'earth-disk', i.e. the earth as a single entity. The word 'eres is the more general term referring either to the (dry) land or ground, or to the whole earth. Genesis 1:9-10 states that the eres was formed as the result of the waters moving horizontally outwards to leave dry land behind at the centre. This produced two spatial domains on earth, namely land in the middle and waters surrounding the land. Many texts in the Hebrew Bible from Prophets to Psalms and Job describe how the earth comes into existence when God establishes the earth by setting it on pillars to prevent the earth-disk from sinking beneath the waters of těhom - the underworld ocean.

\section{Genesis 1:1-3}

Genesis 1:1-3 tells us how this world came into being and this is commonly translated "In the beginning God created the heaven and the earth. And the earth was void and bare, darkness was over the abyss, and God's spirit moved over the waters. God said: Let there be light and light was." A more detailed analysis shows the flaws of this translation. The very first word, běre 'šît 'in the beginning of', marks not an absolute starting point in time, but expresses the starting point of the action expressed by the following verb. The meaning of this verb $b \bar{a} r \bar{a}$ ' has been widely discussed. In van Wolde (2009) the hypothesis is presented that this verb designates 'to separate' as a purely spatial term, a view that was further explained and substantiated in van Wolde and Rezetko (2011). ${ }^{20}$ Based on comprehensive linguistic studies, the conclusion is that the verb $b \bar{a} r \bar{a}$ ' functions in the cognitive domain of space and designates [SEPARATION], [DIVISION], or [SETTING APART]. Dependent on the context it can be translated as, 'to divide, separate, set apart, spread out, disconnect.' Hence, Genesis 1:1 should be translated: 'In the beginning

\footnotetext{
${ }^{19}$ Genesis 1:6-8 uses the term räîa ', 'vault', which refers to the result of either a gold/silversmith who beats out metal/solid plates or of someone who spreads out a plate or other solid material. Based on a metaphorical structuring of this concept, God's making of the heaven is conceptualized in terms of the beating out or spreading of solid plates of the heavenly vault in the endless water expanse.

${ }^{20}$ van Wolde (2009, pp. 3-23), van Wolde and Rezetko (2011, pp. 2-39).
} 
when God separated the heaven and the earth, ...". ${ }^{21}$ The implication is that the sentence is not concluded in verse 1 , but continues in verse 2 . It marks the starting point of the divine action of separation over and against the situation described in verse 2 .

In verse $2 \mathrm{a}$, the following two pictures are painted (1) the earth as tōh $\hat{u} w a-b \bar{o} h \hat{u}$, which creates an image of the earth not yet set on pillars, hence, not yet visible and still covered with the pre-cosmic waters of the těhomm, and (2) a vast darkness over this primeval ocean or těhōm. Verse $2 \mathrm{~b}$ describes how God's ruach or wind/breath hovers over and faces these waters. In this sense, verse $2 \mathrm{a}$ depicts an endless expanse of water stretching out in all directions, covered in complete darkness, whereas verse $2 \mathrm{~b}$ describes God's spatial movement and actions with regard to the waters.

This is a powerful image of what happened when God began to act in a universe that, till then, had only consisted of water. Verse 1 describes the beginning of this action and qualifies it as separation: when God began to separate the heaven and the earth. Verse 2 a continues with the situation that the earth is covered with water and darkness covers the abyss of waters, that is, it zooms in on the condition of the heaven and earth referred to as direct object in verse 1 . However, verse $2 \mathrm{~b}$ zooms in on God's act of separation described in verse 1 . Consequently, verse $2 b$ shows that it is God's breath (or the wind) that separated the primordial waters to make a spatial realm between heaven and earth. In this deep, dark and watery context, verse 3 uses only two Hebrew words to evoke God's first act of creation: "And God said: wayyehi 'o $r$, "Let light be", followed by the immediate result: "And light was". The proposed translation is therefore:

1. In the beginning when God separated the heaven and the earth

2a. The earth was ungrounded and without foundation and darkness covered the abyss filled with waters

2b. God's breath/wind was moving/blowing over the waters,

3a. And God said:

3b. Let light be.

3c. And light was.

Genesis 1:1-3 uses imagery to convey how God's breath or wind transforms a world filled with water. This divine act of dividing by breathing shows us that God does not fill a void (the classical idea of creatio ex nihilo), but rather that he splits the oneness of the primordial waters open to create a new reality.

\footnotetext{
${ }^{21}$ The syntactic structure of this verse is: "In the beginning of (the act by which) God separated the heaven and earth", which in English becomes "in the beginning when God separated the heaven and the earth". Cf. Holmstedt (2008, pp. 353-359).
} 


\section{The Framework of Non-Linearity in Genesis 1}

Genesis 1 is usually read from a chronological and causal perspective. Therefore, the text is understood as a temporal arrangement in which the first thing told happened first and the next thing told happened later. In a chronological reading, the opening verse represents the beginning and the subsequent days show what happens next. In a causal reading, the same text is read as a causal chain: the first element told not only happens first, but it is also the cause of the second element, which is therefore an effect of the first event. In this reading causality will be the story's main theme: everything originates from the creative actions of God. He is the initiator and the created phenomena are the effects of his actions. Causal relationships also occur between the created elements themselves. Water and light are created first and only then can the earth can bring forth plants. These plants in their turn must be created before the animals as they are necessary for the animals to live on. A causal understanding of the text has important consequences because the last element told is considered the most valuable or important (at least this is the way it is interpreted in history). In the Jewish tradition this has led to the conclusion that the seventh and last day is the climax of the story. In the Christian tradition many people infer that humans are the pinnacle of creation, and the 6th day of creation is considered to be the story's climax. On the 6th day God created the human being and with this final creature, creation reaches its culmination, possibly even its goal. According to this causal conception, Genesis 1 is understood as an explanation of the special position of the human being within the created universe: heaven is made for the benefit of the earth, the earth for the benefit of humans, while plants and animals are made to provide the necessary conditions for the human beings to live on earth. However, if this causal approach is applied to Genesis 2 and the story of paradise, a woman ('Eve') is the last creature to be made so we would have to infer that creation reached its climax and ultimate goal when the human female was created. Illogically, the opposite conclusion is usually drawn.

This linear interpretation of Genesis 1 rivals the scientific view, because it understands causality in the same way as science does in the sense that they both provide a linear explanation of the actual causal relations between objects and events (see section above on causality as ontology). However, does this linear arrangement actually apply to the text of Genesis 1 ? Some shortcomings can easily be detected. If linearity were the fundamental device, how can it be explained that God made the light in verse 4, and the sun and moon much later on, in verses 1416? How God could have possibly made the heaven and the earth in verse 1? And do the earth and the heaven exist now, according to the story at this stage? If they do, it is inexplicable that God in verses 6-8 creates a vault in the middle of the waters and calls it 'heaven', and that in verses 9-10 God separates the waters from the dry land and he calls the waters 'seas' and the dry land 'earth'. Does God create them twice? The most striking problem with a linear reading is that Genesis 2 is positioned immediately after Genesis 1. It seems as though Genesis 2:4b-7 starts from the beginning again. "On the day Yahweh God made earth and heaven, the 
earth was without plants and human beings ... and he made human beings from dust of the earth." Yet, this had already happened before, as was described in Genesis 1:26-28. People who read linearly are completely baffled. But what if this linear conception is too limited a view?

In a non-linear reading the text can be explained as follows. The first action narrated is marked as an action by God through which he alters an existing situation or totality by separating the expanses of water into heaven and an earth, and from this point onwards God (and the narrator in the text) focus on the various elements. Over and over again we see the non-linear pattern return. The starting point is totality, and then the text zooms in on the making of one or more of its elements. For example, verse 3 tells us about God creating light, but only later on, in verses 14-17, does the text mention God making the sun, moon and stars. Or, in verses 910 God makes the earth as a whole, while zooming in in verses 11-13 on the plants and trees on earth. Or, verse 1 describes the separation of the waters into heaven and earth, while later on, in verses 6-8, we read that the heavenly vault was created to keep the waters apart. This non-linear form of narration and conceptualisation can also be seen in the two entire stories presented in the first three chapters of the Book of Genesis, namely Genesis 1 telling the story of creation, and Genesis 2-3 telling the story of paradise. In the first story, we are told how God made the human beings on the 6th day (1:26-28). This is a kind of overarching view of what occurs in the second story, when Yahweh God first makes a male human being and then from him makes a female human being while describing the details of their new existence. In other words, the story of paradise refers back to what has previously been told through images of an overarching summary of creation. This non-linear arrangement shows some similarities with fractal structures. The starting point is like a fractal image at the highest level, from where the text zooms in on one element, which in itself exhibits a fractal structure, too. Over and over again, new elements are specified that form new smaller fractals.

\section{The Non-linear Arrangement in Genesis 1 and the Concept of Chance}

In the opening chapter of the Book of Genesis we discover various non-linear arrangements in which the text first introduces the elements in one big picture and, subsequently focuses on one of these elements in detail. Depending on the perspective chosen (i.e., the level of detail zoomed in on) a new kind of 'realm' is revealed. In each realm, the species have their own organisation and responsibilities.

For example, verses 11-12 relate to the plants and trees on earth. God instigates the earth to produce plants and trees, each with its own seeds and fruit in order to reproduce distinct species. The words, 'the seed' is repeated six times in these verses, three times with regard to plants and three times with regard to trees. The 
causative sense of the verb in verse 11 indicates that the plants are conceived as producing the seed, and the seeds themselves are responsible for the process of germination and production of new life in the ground. In verse 12, the fruits of the trees are described as seed containers. The notion that each plant and tree should bring forth new life according to its own species is repeated three times. In this way the text emphasizes both the activity of the plants themselves and their system for maintaining the necessary distinctions between their offspring.

Another example is the animal kingdom. In verses 20-23, God addresses first (in verse 20) two groups of animals: the animals that swarm the seas, and the birds that are characterized in relation to earth and heaven. And the swarming sea animals are blessed and encouraged to be fruitful and multiply and fill the waters of the seas whereas the birds are also blessed but are only told to multiply. However, in verse 21, also a third group of animals are mentioned: the tanninim, the inhabitants of the těhom or the abyss. They are considered to have existed prior to God's creative activities and to differ from the other animals in their origin and procreative abilities. They are not asked to reproduce themselves. In contrast, the sea animals (the second group of animals mentioned in verse 21) are presented as having been brought forth by the waters and they are asked to reproduce themselves in order to swarm the sea. The birds are described as flying over the earth across the sky; they are still related to the earth and to the aerial realm below the heavenly firmament. God assigns each party to its own life sphere, which they have to fill with their own species of animate life, with the exclusion of the tanninim who are not recorded as reproducing new life.

In a cultural framework dominated by a non-linear way of thinking, the concepts of necessity and chance also function differently. In a non-linear perspective, the concept of chance is not understood in terms of a break in a causal or deterministic chain of events, but it stands out in a framework of thinking in which totality and instantaneity alternate. Because Genesis 1 alternates between scales, it does not represent a temporal sequence or a causal arrangement. Thus the reader is made aware of a new sense of coherence at each and every level or scale, and, more importantly, challenged with the lack of necessity for sequence between the various levels. Because of the absence of a causal chain of events, the text of Genesis 1 opens our eyes and shows us the fractal structure of the universe. Chance-so often conceived as the opposite of necessity - turns out to be present in every event depending on the scale and the perspective chosen. In this sense, Genesis does not differ from the view presented by God in his represented speech in the book of Job.

\section{Conclusion: Views on Chance in Job and Genesis 1}

God's speech out of the whirlwind in the Book of Job and the opening chapter of the Book of Genesis both offer a non-deterministic view on chance. Chance is not the exception in a causal or necessary chain of events, but is scale dependent. The view is unmasked that causal relationships have to be conceived as if they are 
ontologically present. In his speech in the Book of Job, God invites its readers to examine their views on the topic of chance as this exposes the human quest for causal explanations that results from the human need for moral order, logical structure, and an understandable system. The text teaches us that chance accompanies our quest for necessity, for moral and logical patterns and our desire to call patterns God's design. In addition, chance is linked to a multifocal view of the universe and understood in terms of position, perspective, and scale. Moreover, the opening chapter of the Book of Genesis offers a non-deterministic view on chance. In Genesis 1, chance is not an exceptional event that disrupts some causal or deterministic chain of events, but rather it is highlighted within a framework of non-linear thinking where totality and instantaneity alternate. In a world, where God zooms in or out on various lower-level components, any claims for completeness or order can no longer be made. In sum, in both Job and Genesis 1, chance is presented as a disqualifier of causal chains and even as an ultimate denial of necessity.

Acknowledgments I would like to thank Lut Callaert, Ruti Vardi, Klaas Landsman, Chris Mollema, and Christoph Lüthy for their comments on earlier drafts of this chapter.

Open Access This chapter is distributed under the terms of the Creative Commons Attribution-Noncommercial 2.5 License (http://creativecommons.org/licenses/by-nc/2.5/) which permits any noncommercial use, distribution, and reproduction in any medium, provided the original author(s) and source are credited. The images or other third party material in this chapter are included in the work's Creative Commons license, unless indicated otherwise in the credit line; if such material is not included in the work's Creative Commons license and the respective action is not permitted by statutory regulation, users will need to obtain permission from the license holder to duplicate, adapt or reproduce the material.

\section{References}

Batto, B. F. (2013). In the beginning: Essays on creation motifs in the ancient Near East and the Bible. Winona Lake, IN: Eisenbrauns.

Clines, D. J. A. (1989-2009). Job. Word biblical commentary (3 vols.: Job 1-20 publ. in 1989; Job 21-37 in 2006; Job 38-42 in 2009). Vols. 1 and 2: Dallas: Word Press; Vol. 3: Nashville: Thomas Nelson Publishers.

Clines, D. J. A. (2004). Job's God. In E. van Wolde (Ed.), Job's God (Concilium 2004/4) (pp. 3951). London: SCM Press.

Cornelius, I. (1994). The visual representation of the world in the ancient Near East and the Hebrew Bible. Journal of Northwest Semitic Languages, 20, 193-218.

De Joode, J. (2015). Landscapes of hurt and healing. An Exploratory cognitive-linguistic analysis of spatial metaphors in the book of job. Dissertation, Catholic University Leuven.

Gravett, E. O. (2012). Biblical responses: Past and present retellings of the enigmatic Mrs. Job. Biblical Interpretation, 20, 97-125.

Habel, N. C. (1985). The book of Job. A commentary (Old Testament Library). London: SCM Press.

Holmstedt, R. D. (2008). The restrictive syntax of Genesis 1:1. Vetus Testamentum, 22, 353-359. 
Horowitz, W. (1998). Mesopotamian cosmic geography (Mesopotamian civilizations). Winona Lake, IN: Eisenbrauns.

Hume, D. (1779). Dialogues concerning natural religion (2nd ed.). London.

Hulswit, M. (2002). From cause to causation. A Peircean perspective. In Philosophical Studies Series (Vol. 90). Dordrecht/Boston/London: Kluwer.

Keel, O., \& Schroer, S. (2002). Schöpfung: Biblische Theologien im Kontext altorientalischer Religionen. Göttingen/Freiburg: Vandenhoeck \& Ruprecht.

Newsom, C. A. (2003). The book of Job. A contest of moral imaginations. Oxford: Oxford University Press.

Niehoff, M. R. (2013). The emergence of monotheistic creation theology in hellenistic judaism. In L. Jenott \& S. K. Gribetz (Eds.), Jewish and Christian cosmogony in late antiquity (pp. 85106). Mohr Siebeck: Tübingen.

O'Neill, J. C. (2002). How early is the doctrine of creation Ex Nihilo? Journal of Theological Studies, 53(2), 449-465.

Pongratz-Leisten, B. (2001). Mental map und Weltbild in Mesopotamien. In B. Janowski \& B. Ego (Eds.), Das biblische Weltbild und seine altorientalischen Kontexte (pp. 261-279). Mohr Siebeck: Tübingen.

Schmuttermayr, G. (1973). Schöpfung aus dem Nichts' in 2 Makk 7,28? Zum Verhältnis von Position und Bedeutung. Biblische Zeitschrift, 17, 203-228.

Seow, C. L. (2013). Job 1-21: Interpretation and commentary. Grand Rapids: Eerdmans.

Smith, M. S. (2010). The Priestly vision of Genesis 1. Minneapolis: Fortress.

Sommer, B. (2009). The bodies of God and the world of ancient Israel. Cambridge: Cambridge University Press.

van Wolde, E. (1995). The development of Job: Mrs. Job as catalyst. In A. Brenner (Ed.), A Feminist companion to wisdom literature (pp. 201-221). Sheffield, UK: Sheffield Academic Press.

van Wolde, E. (2003). Mr. and Mrs. Job (pp. 42-106). London: SCM Press.

van Wolde, E. (2009). Why the verb ברא does not mean 'to create' in Genesis 1.1-2.4a. Journal for the Study of the Old Testament 34.1, 3-23. http://radboud.academia.edu.ellenvanwolde.

van Wolde, E., \& Rezetko, R. (2011). Semantics and the semantics of ברא. A Rejoinder to the Arguments Advanced by B. Becking and M. Korpel. Journal of Hebrew Studies 11(9), 2-39. http://radboud.academia.edu.ellenvanwolde.

Walton, J. H. (2011). Genesis 1 as ancient cosmology. Winona Lake, IN: Eisenbrauns.

White, E. (2014) Yahweh's council (Forschungen zum Alten Testament 2. Reihe, Vol. 65). Tübingen: Mohr Siebeck. 